\title{
A lack of meaning?
}

Reactive nihilism and processual materiality

DOI: https://doi.org/10.30664/ar.91788

(c)(1) Attribution 4.0 International (CC BY 4.0)

$\mathrm{T}$

his article explores the 'lack of meaning' in contemporary society as a consequence of Western dualist thought paradigms and ontologies, via Gilles Deleuze's concept of 'reactive nihilism' following the colloquial murder of God. The article then explores processual and new materialist approaches in the understanding of the lived and carnal self, arguing for immanent and senseful materiality as an ethical platform for religious, environmental, and societal solidarity for tomorrow. For the theoretical justification of the processual approach in understanding the enfleshed self, the article employs John Dupré's processual approach in the philosophy of biology, as well as Astrida Neimani's critical posthumanism, and contextualizes these considerations with Erich Fromm's ethical distinction of being and having.

\section{Introduction}

Western society is often criticized for its consumerism, superficiality, fragmentation of the self, and difficulty in communicating. These and similar reprimands are directed towards capitalism, the overabundance of information, and the new technologies, though the real culprit might be sought for in the conventional ontological presuppositions that make up the objectoriented perception of embodiment structures in the West and are widely criticized today by new materialist ${ }^{1}$ and 'lived-body'

1 Such as Elizabeth Grosz (1994), Astrida phenomenology authors ${ }^{2}$ alike.

Besides the new materialist theories, the theoretical background of body-ontology connectivity with societal phenomena is particularly exemplified by the critiques of capitalism of Gilles Deleuze and Erich Fromm - two very different authors, who, however, allow an analysis of the distinctions of being, becoming and having as theoretical models for expressing the genealogical, non-essentialist link between ontologies and societies. Having elsewhere further elaborated the necessity for using genealogy in a natureculture context (Sauka 2020), I here seek to specifically address the ethical use of processual new materialism for breaching the rift between human and life sciences and seeking meaning in life whilst staying with the trouble (Haraway 2016) of today's scientific developments.

Hence, in this article, I propose to view the problem of seeking meaning in life in connection with the ontological paradigms of the body, arguing for a genealogical link

Neimanis (2013, 2014, 2017), Jane Bennett (2010), Rosi Braidotti (2013, 2019), Stacy Alaimo (2010), Karen Barad (2007, 2017) and many others.

2 In particular, Bernhard Waldenfels (2000) and Gernot Böhme (2003, 2019). 
between an understanding of the body and ethical and social praxes and attitudes. To demonstrate this link, I contrast an objectoriented understanding of the body and the resulting 'reactive nihilism' ethical paradigm with that of a processuality of the lived body, suggesting that the binarity, still prevalent in Western thought formations, is deeply connected with the so-called lack of meaning, a reversed dualism that hampers the relationality of life and human sciences.

Against the backdrop of a link between the sociopolitical discourse of 'reactive nihilism' (Deleuze 2006: 151) and an understanding of the body, this article searches for an ethical platform for facilitating solidarity between different (scientific or religious) perspectives in processual and materialist ontologies of the body.

The article can, of course, only endeavour to highlight a few significant factors contributing to the breach of human and life sciences and the resulting rift in spiritual and scientific approaches of life in everyday contexts. The methodological approach here is, therefore, genealogical (Sarasin 2009; Foucault 1977), striving to exemplify today's Western attitudes via the example of meaning-making and figurations of the body. Discourses here are viewed in a materialist context as nonessentialist co-producers of lived materialities (Sauka 2020).

The article goes out from the assumption that although scientific contexts greatly vary (and do not per se justify an objectoriented or dualist worldview), the 'reactive nihilism' paradigm often pushes human science and spiritual experiences into the realm of the 'supernatural' or 'imaginary', whilst also denying their ontological validity. Often conventionally viewed from the viewpoint of a dualist mindset, spirituality and human science in a broader sense in the West have become the actual 'ghost in the machine'. As a phenomenon sitting on the very fringe of dominant viewpoints for the ethical making of meanings and worlds (Campagna 2018), spirituality, is a concept in line with the idea of a need to re-enchant the world (Stiegler 2014) and functions as a vehicle for presenting the genealogical landscape of the discourse cluster of 'reactive nihilism'.

I strive to outline an immanent and processual view of the lived body as a platform for varied spiritual beliefs that allows overstepping the usual conflictual relationships between scientific skepticism and atheism and religious faith-based convictions and praxes.

The aforementioned problems are today broadly discussed in new materialist and posthumanist contexts. As one such example, the inspiring article collection Entangled Worlds: Religion, Science, and New Materialisms (Keller and Rubenstein 2017) can be mentioned. What is important to me here, is to delineate the everyday paradigm of reactive nihilism in the West that follows a simplified binary and objectoriented thought pattern, regardless of concrete theoretical approaches in sciences, and creates the (unnecessary) rift between human and life sciences, as well as spirituality and materiality in the understanding of life.

To do this, I turn to Deleuze's concept of 'reactive nihilism' originally developed for the analysis of Nietzsche's commentary on modernity, in the first part of this article and apply this principle as a characterization on the ideological backdrop of today's societal discourse in the West. Here, I go beyond Deleuze's original intention, bringing the ontology of the body in conversation with reactive nihilism to demonstrate the ontological tie between object-orientation and nihilist discourse.

In the second part of the article, I 
discuss the processual approach in ontology, based on Astrida Neimanis and John Duprés approaches in posthuman phenomenology and the philosophy of biology respectively. Although I am aware of the rich array of authors discussing these topics in new materialist circles, I particularly address these theories to exemplify the congruency of science-oriented and spiritual environmentalism-oriented philosophies and their potential for ethical consistency and co-productivity.

In the third part of the article, I then apply Erich Fromm's distinction of being and having as compatible with Deleuze's idea of becoming, here again broadening the usage of this conceptual distinction. The conceptual distinction of being and having here is exemplary of the broad scope that object-oriented and processual ontologies provide and suggests this distinction as an underlying issue in Western society that continues to haunt sociopolitical discourses in varying forms, as an almost inescapable tension created by the existential perceptions of the body and the self. My aim here is to also delineate the limitations of a processual approach, stating existential having as a necessary element of self-perception that upholds the tension between becoming and having that is interpreted as a dialectic of I and the Other (Deleuze 2006: 8-10).

\section{A lack of meaning: the nineteenth-century physiology discourse}

The context of the situation might be sought for in the concept of the 'death of God'. When Nietzsche utters his bold accusation: 'God is dead, God remains dead and we have killed him' (Nietzsche 1999a: 481), it is a sociopolitical statement. The nineteenth century comes in with what is sometimes referred to as the physiology discourse (Sarasin 2000: 51-2), replacing the
Cartesian image of the body as a machine with the 'human machine' metaphor (Sarasin 1998: 419-27) that adds sensibility and motion to the previously mechanical vision of a subject-controlled res extensa. In the eighteenth century, scientists still try to elaborate the already-objectified understanding of a body, understood as a device, even by looking for empirical evidence of a soul (Sennett 1994: 259). However, the discoveries in blood circulation, nervous system and breathing (ibid. pp. 255-61) do not result in the affirmation of a centralized control system of the body with the brain or heart as the only venues of nerve-response or sensibility, but rather a facilitated decentralization of forces in the understanding of the body, as well as society.

An expansive objectification of the 'nature' of humankind is, hence, unsurprising - the seventeenth-century image of the body as a machine has already put Western society on a path towards further objectification and fragmentation of life forces; viewing the human body as measurable on the grounds of a mechanical understanding of 'nature' inescapably leads to the acknowledgment of physiological phenomena (such as the functions of the nervous system, and later the endocrine system and hormone production) as part of the scientifically researchable arena. From the objectification of 'nature', the objectification of human and non-human bodies logically follows ${ }^{3}$ and, thus, societies in the West

3 I here follow the argumentation of Michel Foucault (1978) (taking into consideration materiality in Foucault, see Oksala 2005) and the overall Foucauldian line of research, in line with my overall research goals to synthesize social constructivist and new materialist/lived-body phenomenology genealogies of the body and examine the impact that body-perceptions and 
come to an objectification of themselves, as more and more data speak for the measurability and physiological foundation of all human experiences.

However, whilst the sphere of subjectivity crumbles, with the discourses of science, hygiene, and physiology becoming stronger, simultaneously an inflation of individuality is experienced. The scheme is surprisingly simple. Whilst the individual gains worth in the context of Enlightenment humanism, the spheres of freedom, autonomy, and indetermination are incommensurable with the sphere of a mechanically-conceived 'nature', and thus are conceptualized extremely narrowly. In the works of Immanuel Kant, for example, it is the pure reason and rationality that are thought to be worthy of freedom and equality, whilst the rest of human and nonhuman expressions are objectified via the scientific gaze. One shall be free and equal as beings endowed with a rational mind - a view in itself problematic and tied to the paradigm of human exceptionalism (Haraway 2007: 11).

As a result, the 'mind' or 'reason' cannot defend their freedom outside of a senseful, irritable body - this sphere is so narrow, it cannot be traced, and, ultimately, it is erased, caught between the incompatible binary extremes of a 'brain' as nothing more than a physiological function and a 'subject in discourse' - as a product of the poststructural historicity. Simultaneously,

materializations have on the ethicosocial sphere. Thus, whilst I recognize the multiplicity of scientific views, I briefly outline the predominant line of 'scientific discourse', as it is embedded in everyday experiences in the West. This seems especially important, given the material impact different ideological constellations cause. Thus, simply put, the way one thinks of science affects science and its results. with the 'decline of the soul' (i.e. the death of God) human world-making (Campagna 2018) in the West has lost most of the space for anchoring 'meaning' and 'values', which are then mostly encapsulated in the idea of a rational mind. Thus, already by Kant, a 'reversed dualism' comes to the fore - namely, whilst body and mind in the West are largely not thought of as different substances, capable of existing separately, 'mind' and 'body' are still in a hierarchical relationship and form a dialectical distinction; only 'mind' (replacing 'soul') becomes in a sense fictitious and ontologically second to the body, which is, however, stripped of meaning and mechanically organized (see Lacan 2006). The 'reversed dualism' of reactive nihilism still maintains the figuration of the thingness of nature as opposed to the 'spirit' for which there is no place other than the fictitious/physiologically grounded realm of the mind, yet it continues to uphold the ideal of controlling the seemingly determined and mechanical 'body'.

These supposedly non-dualist, yet ethically dualist, attitudes of contemporary sciences are, I think, best exemplified in the works of Nikolas Rose (Rose and AbiRached 2013: 200-5), who characterizes the advent of neurosciences and their 'residue on the socius' (Deleuze and Guattari 2000: 281) in the reconceptualization of the human self. Paradoxically, this neuro-centric view of the human self also maintains a transhumanist picture of a mechanistic, but transformable nature, as well as a 'materiaphobic' (Keller and Rubenstein 2017: 5) dream of overcoming the 'errors of nature', recapturing the dream of transcendence and immortality on Earth. Dualism is still prevalent, it is still in action; only now it is turned on its head.

This is not the 'faith in Earth' Nietzsche talked about, stating that our lived bodies 
are the 'big mind' (Nietzsche 1999b: 39) - a statement that highlights relationality and multiplicity. It is an entirely dualist materialism and, at that, one that seeks eternity not in heaven but now on earth. Transcendence still prevails, only now it is materialized, encapsulated into a cancerous (Deleuze and Guattari 1987: 163) vision of life that could be fixated, stopped, idealized.

The reactive nihilism does not change the objectives for a human future (Deleuze 2006: 149-51), but rather recaptures them in a secular setting, enabling a kind of sacralized secularity. Instead of the homo sacer (Agamben 1998), there might now be a similar 'state of exception' for our brains: a neuro sacer. The neuro-logical is sacred - renowned as our hope for tomorrow, yet it can be transformed and bent to our will - and, thus, it is simultaneously with and without power, a continuation of the reactive nihilism that encapsulates our hopes for transcendence in our bodies.

This is an essentialist, objectified image of a body that overturns the discourse of flesh and soul, only to constitute a new kind of dualism, where the objectivelycast embodiment undergoes sacralization, whilst the self acquires the status of an 'illusion'. The conceptual problem is clear - if we, as humans, objectify our surrounding world, we end up objectifying ourselves humanity is, after all, just as measurable and calculable as anything else, if the calculability and determination of all life are presumed. It is the objectifying gaze turned inward to make sense of the world, which then appears ever more senseless than before.

Thus, the sociopolitical discourse in the West is largely built upon a reductionist understanding of science, where faith and philosophy are replaced by data, experiments, and objectification. The world 'discovered' as an object of science moves farther and farther away from the lived experiences of the human and non-human selves, among other things causing doubt concerning the applicability of human science to any 'real-life' occurrences. If not tragic, this situation might be thought of as ironical, seeing how the human sciences largely cause the establishment of ideas that guide us, including ones that eliminate the necessity of themselves.

What is important, however, is not to jump to a conclusion that a return to the killed God should be the only possible solution for a re-enchantment of the world. For who was the killed God in this context? Why, it was the God that led us to be killers - namely, as Deleuze put it: 'negative nihilism is replaced by reactive nihilism, reactive nihilism ends in passive nihilism. From God to God's murderer, from God's murderer to the last man' (Deleuze 2006: 151).

The reversion of dualism is already there in the statement. With negative nihilism in Nietzsche's thought, Deleuze understands the 'no' saying to the world (Deleuze 2006: 147-8) which Nietzsche sees in the social discourse of institutional religion. However, a reading that I would propose would take a slightly different path; namely, it might be necessary to ask - why would religion be mentioned at all in the context of scientific world-building here, in the context of lived discourse constellations? After all, religious and spiritual views widely differ, and the same can be said for scientific ones. The relation of religion and science here might be connected with Christian 'materiaphobia'. In the words of Catherine Keller and Mary-Jane Rubenstein: '...the major religious traditions also carry long normative routines of disembodiment. Christianity in particular has long suffered from a condition of we could call "materiaphobia" (Keller and Rubenstein 2017: 5).

Namely, the dogmatic worldview 
Nietzsche speaks of is a societally-embedded religious 'materiaphobia' characteristic to Christianized Western countries in a specific time-space, also in connection to scientific developments of the time (see Keller and Rubenstein 2017: 5-7), rather than a specific religion per se. Thus, 'materiaphobia' (which by no means exhausts the religious traditions but is represented in Nietzsche's thought as the not-yet-killed God) causes its reversal, via transferring these same thought patterns to modern science. In a sense paradoxically, the not-yetkilled God enables the reversal of dualism in reactive nihilism, causing the (partial) extinction of a religious worldview (including that, which enabled the scientific discourse). Simultaneously the process also dispels the possibility of seeking meaning in the flesh, which is still viewed within the context of the 'materiaphobic' thought patterns. ${ }^{4}$

Where negative nihilism saw the condemnation of flesh and materiality and exiled materiality as fictitious and illusory, reactive nihilism does the same with the 'soul', eliminating meaning. All that exists is the supposedly objective, deterministic physical world, which is why one should seek an eternal life on earth, try to progress, try to ascend and transcend our lived realities, by enhancing the reasonable man beyond the flesh, via bodily (largely technological) means, as is best exemplified by the Enlightenment-inspired transhumanist $(\mathrm{H}+$ ) paradigm (Braidotti and Hlavajova 2018: 439). Science takes the place of religion, but it does not change the stakes.

4 As described further, the developments of science, however, again lead our thinking back to the embeddedness of meaning in the flesh, as also explained by Karen Barad (2017: 26).
What does reactive nihilism result in? For one, it structures a new kind of dogmatism - 'you shall believe' becomes a 'you shall not believe', at least not unless we have evidence in the form of persuasive data. 'If ... then' is the new rule, and one should not depart from it. 'If there is no proof' one should not believe in God, seems to be the contemporary mantra. Does it not sound ludicrous? Logically one can only presume it could mean that one must not believe, but where does the imperative come in? Yet, often this is the atheist motto, echoed, for example, in the philosophies of the 'four horsemen' 5 of the new atheism.

With that one is still faced with an imperative; only now it is secularity that becomes sacral, the body being its vessel of truth, the most extreme expressions of which are witnessed in fascist and eugenic movements and the communist totalitarianism of the USSR, where religion is outright banned. It serves to mention that the objectivity of science, is, of course, no factual objectivity. To forgo the inescapable social constructivism of science, founded on its reliance of the existing symbolical orders (Dupré 2012: 40-54) since its invention, coupled with sociopolitical objectives, next to the most glaring examples, such as the so-called scientific materialism of the USSR, the scientific discourse has experienced various other mishaps - the biological determinism of the sexes (Laqueur 1992, 1987; Moi 1999: 19-20) being among them.

Whilst defining the grounds of knowledge as objective research, instead of metaphysical belief or faith, science too seeks to justify social discourses, changing the means of justification, but not the argument

5 Richard Dawkins, Daniel Dennett, Sam Harris, and Christopher Hitchens. 
itself. Religion goes on, but maybe not so spirituality.

\section{A change of heart: processuality and the becoming self}

Scientific reductionism, however, has experienced its decline. Interestingly, whilst religion has taken part in the rise of science, science again gives rise to a different kind of spirituality. In the words of Karen Barad:

The point is also to understand how science deconstructs its own authority: how its own findings undermine the very modernist conceptions on which this progressive narrative rests, such as the scientific belief in the immutability of matter, the Newtonian conception of time as an external parameter that marches forward without interruption, determinism, the nature/culture dualism, and human exceptionalism (Barad 2017: 26).

More and more clearly, science admits its social constructivism, finding new paths of discovery and implementing new models of analysis. Simultaneously, symbiosis (Margulis 2001) and a processual understanding of bodies and their interactivity gain significance (Braidotti 2013; Neimanis 2017). Recently, for example, we have started to investigate the mindgut connection (Mayer 2015), as well as viewing decision processes as potentially co-directed by several organs, rather than being a brain-centered event.

Within the neurosciences, concepts such as plasticity come to the fore, and emotions are by now accepted as indistinguishable from reasoning processes (Damasio 1994, 2000). Biology inspired investigations into mushrooms (Tsing 2015; Sheldrake 2020), and other life-forms that we live with, also gain traction (Dunn 2019) in human and life sciences alike.

Similarly, the hygiene discourse of the nineteenth century is gradually compromised by the newly-discovered benefits of the so-called 'good' bacteria, as well as their role in the development of life, not to mention the ardent discussion on anti-biotic resistances facilitated by excessive antibiotic use. Moreover, climate change, as well as the current COVID-19 pandemic, forces society outside of academic circles to rethink the outer boundaries of our bodies and subjectivities. Responses to climate change, in particular, increasingly paint a picture of a subject-in-process (Kristeva 1984: 22; McAfee 2004: 29-42), permeated by micro-plastics and other seemingly alien particles that have now become a part of ourselves (Neimanis 2017; Braidotti 2013; Alaimo 2010).

In the philosophy of biology, this realization is reflected in John Duprés proposition of a processual philosophy that would prioritize symbiosis and process over branching and substance-centered approaches. This approach leads to a nonhierarchical understanding of the sciences, as well as allowing for a constitution of the symbiotic character of the living world.

One of the most significant consequences of the processual hierarchy of the living world, then, is that it makes the physicalist dream of absolute reductionism impossible. ... It also means that we cannot pick out any level in the hierarchy as ontologically or causally primary. Whereas a substance ontology that presupposes a structural hierarchy of things only allows bottom-up causal influences, a process ontology has no trouble in recognizing that causal influences can flow in different directions. (Dupré and Nicholson 2018: 27) 
The processual approach in the philosophy of biology is reflected also in critical posthumanist explorations that highlight enfleshed but meaning-making understandings of life processes, accentuating that whilst life should be understood on the plane of immanence (Deleuze and Guattari 1994), it does not require us to draw a mechanical or meaningless picture of the world. Quite on the contrary, a materialist approach necessitates not only the reformation of our views of subjectivity and the self, but also a recapturing of biology and materiality as part of the unfinished, historical lifeworld. Thus, for example, in the opening paragraphs of her book Bodies of Water the feminist posthumanist Neimanis highlights this porousness of the body via the concept of water, stating:

To rethink embodiment as watery stirs up considerable trouble for dominant Western and humanist understandings of embodiment, where bodies are figured as discrete and coherent individual subjects, and as fundamentally autonomous. Evidence of this dominant paradigm underpins many if not all of our social, political, economic, and legal frameworks in the Western world. ... But as bodies of water we leak and seethe, our borders always vulnerable to rupture and renegotiation. (Neimanis 2017: 2)

Neimanis's conceptualization of phenomenology and posthumanism as compatible paradigms demonstrates that the porousness of the body should not be viewed as an even stricter physiologization, but rather as a basis for the realization that the materiality of bodies and our enfleshedness does not constrain the conceptualization of a senseful selfhood, but rather enables it. This approach resonates with
Donna Haraway's expression 'staying with the trouble' (Haraway 2016) - rather than moving away from the body, to seek refuge in the neuro-centric life sciences today, human sciences and spiritual approaches currently engage with what is already given, to accentuate the possibilities of a senseful understanding of immanent materiality in all its multiplicity and relationality.

Thus, the theorization of the porousness of our bodies is an opportunity to establish a more holistic picture of the human body as a becoming, historically embedded entity that is more of a process than a concrete object or a thing. What we are is materiality and energy, yet, without disintegrating mind from body or reason from emotion, a processual, becoming, historical selfhood comes to the fore that is just as much spiritual as enfleshed - that is Leib or carnal body as the 'big mind' (Nietzsche 1999b: 39; Waldenfels 2000). If all the experienced emotions, feelings, thoughts, and affects are materially embedded, materiality itself loses its determination, objectivity, and fixation and becomes a living, breathing part of our worlds.

Current developments in biology (such as the Human Genome Project, Dupré 2012: 102-5; Rose 2007: 17) clearly show that materiality does not presuppose 'thingness' 6 , but the symbiotic nature of bodies

6 If we were to view the world through the eyes of quantum physics, for example, materiality would even necessitate us to presume that immanence should also be paired with a sort of transcendental view, as far as 'transcendental philosophy presents a sustained attempt to problematize natural realism as our taken-for-granted view of reality' (Oksala 2016: 4-5), as the actual matter and energies are only phenomenologically conceived in their concreteness and could well be thought of differently, should we not be humans, but aliens, with radically different perceptive powers. 
has hitherto been obscured by the weight of autonomy, which now seems to press us to accept a determined lifeworld, with the realization of the technicalities involving our bodies. Thus, still constrained by the reversed dualist notions, one is often compelled to think the hormone-induced anger might be less important or, indeed, 'less human' than a 'reasonable one'. Such a distinction between real vs. hormonal feelings is doomed to gradually accept all human emotion as hormonal (as in, involving a material process), devaluing 'real' emotion to the status of illusion, 'a trick of mind'.

Take the example of hormonal anger: it can only be accepted as different in kind to 'actual' anger if one supposes that it is not instigated by environmental factors, such as 'a bad situation'- but, then, how could it be transformed with the intervention of other environmental factors? This might seem like a simple linguistic misunderstanding, but in fact, it goes much deeper than that. Nikolas Rose (2019: 111-15), for example, accentuates how our presuppositions of the main source of mental illness, which today is thought to be in the brain', completely change the way that these illnesses will be treated, highlighting the problematic acceptance of the 'chain of causation':

... there are many logical flaws in this line of reasoning, most crucially the assumption that the key direction of causation is from brain processes to mental life and behaviour, and hence that to intervene in abnormal - or even normal - mental life and behaviour, one should intervene in those brain processes (Rose 2019: 113).

The misrepresentation in reductionism seems evident. The very idea that we can and should interfere with our brain or other bodily processes, is also the first most evident proof that the milieu does constitute a significant part of the 'chains of causation', for how else can any intervention occur? A similar argument is also made by John Dupré, speaking of ADHD medication for children, who argues that, instead of attempting positive changes in environments, governments choose to point to the defects of individuals, excluding the problem of the milieu (Dupré 2012: 36).

The construction of 'hormonal vs. real', pushes us towards a dangerous game of reactive nihilism, which highlights the materiality of discourse - the way things are conceived influences strongly their production and becoming, thus, also affecting their materiality - which is also a reason for rethinking body conceptualizations in ethical contexts. The acceptance of materiality in a pluralist and processual manner, can, thus, allow moving beyond a dualist undervaluation and mechanization of materiality.

\section{The ethical predicament of becoming and having}

Yet, despite promising theoretical models, inherent dualism has hitherto prevailed in social attitudes and praxis; popular media outlets continue to force a reductionist understanding of the body and consumer society in the West still leans heavily on reactive nihilism and the sacralization of secularity. This situation is characterized also by the ontological disposition of human beings, which unavoidably drives towards conceptualizing oneself and the environment via some kind of objectification, and thus also creates a rift between the self and the surrounding world.

The ethical consequences of the ontological models, represented in the carnal body phenomenology via the 'carnal body that we are' and the 'body that we have' 
(Böhme 2003: 26; Fuchs 2013: 82-93) are depicted by Erich Fromm, who differentiates between being and having 7 (Fromm $1976,1992)$ - as two possible modes of living. Being is associated with life, activity, process, taking action, creativity, and meaning, whilst living in the mode of having points towards death, passivity, object, narcissism and superficiality, namely, a lack of meaning, which, as per Fromm, is associated with the contemporary capitalist society.

Despite the linguistic duality, this distinction can be shown to avoid the dangerous contraption of binary thinking. Having, for Fromm, is always also existential having (Fromm 1976: 85), the unavoidable objectification that being human presumes, and an inherent part of being.

Existential having highlights the objectifying abilities of humans - a characteristic of the carnal self that facilitates its selfalienation - namely, via the ego-function, the carnal, enfleshed self views the world via the power of objectification, acquiring also the ability to view the self as a concrete thing, to be preferably preserved and stopped in time. The self, however, is only possible in constant movement and transformation, and thus, a perceptual dialectics between two equally self-preservatory powers ensues, whilst the objectifying power is ontologically rather a 'tool' for the 'big mind', as described by Nietzsche (1999b: 39).

A pathologization of having orientation in life occurs with the proliferation of narcissistic, passive passions (Fromm

7 In new materialist and Deleuzian contexts, as well as in reference to the carnal body (Leib) phenomenology, the distinction of being and having might be more precisely termed as a distinction between becoming and having (see Sauka 2020).
1976: 69-83), which include also the selfpreservatory striving to encapsulate and stop life in its tracks. Via his argumentation reactive nihilism could be depicted as a pathologization of the mode of having. Fromm (1976: 82) states: 'But perhaps more than anything else, possession of property constitutes the fulfillment of the craving for immortality, and it is for this reason that the having orientation has such strength'

Reading Fromm in a new materialist context, the pathologization of having becomes closely tied to the reversed dualism of 'reactive nihilism', which also seeks refuge in the immortalization and fixation of an autonomous self on Earth. If cultural activity is societally perceived as primarily mediated via the ego-function of a lived body, individuality is necessarily contrasted to the symbiotic realities of our material existence. If meaningful life were to be assessed as only possible via this objectification (i.e. self-awareness of a world differentiated from oneself), autonomy and individual agency seem to naturally exhaust the ethical narratives.

To justify solidarity or a joint experience of life, it should then be built up from individual experiences, namely, constructed, by providing evidence for its necessity. Similarly, if we assume autonomy as the starting position of bodies, we then are faced with the problem of the Other, as well as with the problems of 'other minds' and 'mind-body' causation. This problem is, nevertheless, rendered non-existent if the primacy of otherness, of being-togetherbefore-we-are-alone, should be accepted. This primacy of the other, however, should avoid constituting another imperative, but rather move beyond the borders of the self and other entirely. In the context of a process ontology, we are permeated by an enfleshed otherness. As symbiotic beings 
we should, thus, not start from a distinction, but rather with the question of 'how' we are together?

A reading of Fromm also shows the inherent limitations of a posthumanist othering of the self, as via existential having direction of self-preservation a sense of selfhood resists total annihilation of subjectivity and maintains the position of intentionality. Hence, a perceptual dialectic always reconstitutes itself. What a reconceptualization of the self within the concept of becoming can change, however, is the primacy of becoming over having, thus, mitigating the potential of pathologization in the having dimension.

In an ontological context this relation between existential, unavoidable objectification that is part of our self-awareness and our experience of life as a becoming and a process, might be expressed via Nietzsche's terms of the Apollonian and Dionysian forces and their mutual dance (Nietzsche 1999c: 25-38). There is always a 'third', an 'event' taking place here, which is the relation between these forces that balances them out. This is, however, problematic, when the Socratic element emerges (ibid. pp. 83-8) - an element that aspires to establish an 'only' truth, namely, the pathologization or the cancerous version of the having directionality.

Becoming and having, hence, should not be juxtaposed as a mutually exclusive binary opposites, or else a new kind of dualism ensues - you shall not objectify, which becomes an objectification itself. An 'if ... then' of a different sort, where all having directionality in life could be blamed, even though it is unalienable from our experience as human beings and justifies the idea that we are all in it together, but not all the same (Braidotti 2020), and thus enables discussions on ethics and meaning-making processes.

\section{Conclusion: posthuman spaces - solidarity for tomorrow?}

A reversed dualist understanding is both ontologically as well as ethically problematic and creates rifts between religious and non-religious people, different religions, and sciences - especially when speaking of the actual, experienced enfleshedness in the current, lived world. Moreover, as the widespread consumerism and experienced lack of meaning in Western societies show, an object-oriented understanding of the autonomy of bodies creates a fertile ground for hedonistic utilitarianism (Fromm 1992: 3) within the reactive nihilism paradigm - and with it, also for the no effort/no pain doctrine (ibid. p. 24) that suggests to us a spirituality of the consumer type - do whatever it takes if that makes you better workers and more effective society members. Enhance yourself through workouts or religion, if it facilitates a 'feelgood' mood or motivates for efficient work. Fromm argues that, as work in capitalism is understood in monetary terms, as a way for earning money for consumption, 'leisure time' increasingly passivizes the consumer: 'Man has become the suckler, the eternally expectant and the eternally disappointed' (Fromm 1994: 32-3).

It could be argued that religion in capitalist societies also acquires the status of a consumer good that can be 'used' and 'applied' for enhanced efficiency or as a mood-enhancer. I think it is best conceptualized by this quotation by Slavoj Žižek, commenting on the 'spiritual logic of late capitalism':

No wonder that tantra is so popular today in the West: it offers the ultimate 'spiritual logic of late capitalism' uniting spirituality and earthly pleasures, transcendence and material benefits, divine experience and unlimited 
shopping. It propagates the permanent transgression of all rules, the violation of all taboos, instant gratification as the path to enlightenment; it overcomes old-fashioned 'binary' thought, the dualism of mind and body, in claiming that the body at its most material (the site of sex and lust) is the royal path to spiritual awakening. (Žižek 2010: 7, italics in original)

Žižek's argumentation, however, misses the point that instead of a transgression of dualism, it is rather a reversed dualism that has come to the fore. Principally, this quote demonstrates this particular understanding of the body that has developed in the context of the discourse of physiology. Namely, society in the West is faced by a hedonistic utilitarianism, an imperative of maintaining and enhancing one's body, and the sacralization of new, fit and strong bodies, which then also presumes either no religion beyond scientific discourse, or a fasttrack religion that works as a 'magic pill' for human effectiveness and societal success.

What is important here is to remember the symbiotic and processual nature of human enfleshedness. If the body is rephrased in its processuality, the enfleshed self becomes part of the world, a living inside and around our environments, coconstituting life as we know it. As part of processes in the world, meaning is constituted as a doing, a happening, and an event. Meaning is not something one captures and constrains in objects. Rather, it is processual, and, thus, intercarnal - we all connect and intersect on all possible levels. Upon the basis of such a processual view, responsiveness and intentionality can be viewed as balanced, outside an imperative of autonomy.

I would like to exemplify the matter with the seemingly immaterial example of joy, inherited from Spinoza's philosophical ethics (Deleuze 1988: 25-9) and stated as the central virtue in Rosi Braidotti's affirmative posthuman ethics of joy (Braidotti and Hlavajova 2018: 221-4), as one of the most life-affirming emotions.

To define 'joy' in an ethical context Erich Fromm's argumentation might be employed. In To Have or to Be? (1976), he contrasts joy to pleasure:

Joy is the concomitant of productive activity. It is not a 'peak experience,' which culminates and ends suddenly, but rather a plateau, a feeling state that accompanies the productive expression of one's essential human faculties. Joy is not the ecstatic fire of the moment. Joy is the glow that accompanies being. (Fromm 1976: 117)

Joy lights up the whole room, joy can create an atmosphere. It does not function in isolation - we are together in joy, joined, before conscious action is taken. Thus, joy allows us to experience how it is to be joined before we are divided. Joy is also importantly a process, a felt sensation (i.e. it is carnal or leiblich), it can be felt in the stomach, but at the same time it extends our bodily borders beyond what is usually conceptualized as a border - we can feel joy as togetherness, it is something that exists beyond the self. It is also fleeting as well as transformative. Thus, joy seems to constitute a clear example of materiality and enfleshedness in a senseful setting.

Similarly, one could analyse all the rest of emotions, feelings, affects and other sensations that exist in our relationship with the world, rather than in us as autonomous subjects, but it seems that joy best exemplifies the intercarnal aspect of senseful activities that include also spiritual experiences of humankind, and is inclusive; that is to 
say, it reflects sensations that go outside a species limitation. The multiplicity that we are is changed and supplemented but never ceases to be and become, and with this persistence allows conceiving an enfleshed selfhood.

Becoming always already precedes the direction of having and is the founding force of any kind of selfhood to form. The self might fear its instability and fragility, as the ego-function longs for fixation, for identity, for anchoring what 'we are' into a comprehensible, thing-like form. Transformation and process, however, are at the very core of what 'life' is - without motion, no life can be imaginable. Think of Immanuel Kant's depiction of a dove: 'The light dove, in free flight cutting through the air the resistance of which it feels, could get the idea that it could do even better in airless space' (Kant 1998: 129).

The very instability anxiously questioned and examined by philosophers of many kinds, is at the base of how the self continuously becomes a self - a transformative, embedded and enfleshed self (think of the butterfly) that is also intercarnal and lacking in fixed boundaries, not only on the inside, between the elusive ego and the preconscious 'other' of our flesh, but also on the outside, between the carnal body and the other of the surrounding space.

This co-constitution leaves us with an instability that is nevertheless also a creative space for manifold interpretations of spirituality, sense, and meaning - the founding discontinuity does not consist of reducible particles, it is rather a pluralistically interpretable symbolic field, open to a Nietzschean perspectivism. Viewed via a nature-culture continuum, the carnal, processual, and responsive self can be constituted as senseful materiality, nonessentialist, but always transformative - a site of history and agency alike. The if ... then' limitation recedes, and one is not compelled to answer to the question as to whether we are hormonal or angry, as obviously both are true, and neither is possible without the other.

Here I would like to argue that the construction of such lived materiality is congruent with spirituality or an assumption of a deeper, spiritual meaning of life - simultaneously, it does not exclude also non-religious attitudes, as it does not presuppose any essentialist meaning, but rather evidences that the source of all senseful life is embedded and enfleshed, as well as intercarnal, as bodies extend well beyond the borders of any concrete thing or entity, and we are thus existing and co-created symbiotically with all other life always, not only before the moment of being born.

I argue that this is the space from which ethical meaning-making and solidarity in thinking can be sought for - a common ground of not-knowing, non-fixedness, discontinuity, and contingency. A common indetermination that, nevertheless, also includes our enfleshed cultural multiplicity and opens the horizon for posthuman affirmative ethics that includes differentiation and a multitude of interpretations as an ontological predisposition, not a problem to be solved in hopes of achieving autonomy from the colloquial 'air' that sustains life and the processual self. Besides demonstrating the obvious ethical limitations of a negative or a reactive nihilism, the 'blind spots' of dualism also further justify immanent materiality as a solution for seeking spirituality, not in some excluded, isolated factors of our being, but rather in the entanglement of life. To not seek something 'out there' (whether an uploaded consciousness or a heavenly abode), but rather turn towards the being - among other in solidarity with our fellow beings in this dance of life. 


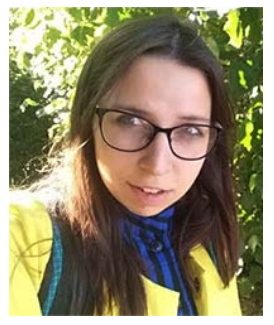

Anne Sauka is a lecturer and researcher at the University of Latvia, in the Department of History and Philosophy, where she delivers and prepares courses for BA and MA level students in philosophy. In her doctoral dissertation (2015) she strives to establish a link between carnal body phenomenology and a socially constructed body, conceived via Foucault's genealogical approach. Her research interests include questions of the body, genealogies, biopolitics, critical posthumanism and environmental humanities, and in her research she focuses mostly on the understanding of enfleshedness and ontologies in context with their sociopolitical consequence, trying to navigate the stormy waters of a materiality understood beyond essentialism.

\section{References}

Agamben, Giorgio. 1998. Homo Sacer: Sovereign Power and Bare Life, trans. Daniel Heller Roazen (Stanford University Press).

Alaimo, Stacy. 2010. Bodily Natures: Science, Environment and the Material Self (Bloomington, Indiana University Press).

Barad Karen, 2007. Meeting the Universe Halfway: Quantum Physics and the Entanglement of Matter and Meaning (Durham, NC: Duke University Press).

- 2017. 'What flashes up: theological-political-scientific fragments', Entangled Worlds: Religion, Science, and New Materialisms, eds. Catherine Keller and Mary-Jane Rubenstein (New York: Fordham University Press), 21-88.

Bennett, Jane. 2010. Vibrant Matter (Durham, NC: Duke University Press).

Böhme, Gernot. 2003. Leibsein als Aufgabe: Leibphilosophie in pragmatischer Hinsicht (Kusterdingen: Die Graue Edition).

- -2019. Leib: Die Natur, die wir selbst sind (Berlin: Suhrkamp).

Braidotti, Rosi. 2019. Posthuman Knowledge (Cambridge: Polity Press).

- - 2020. "We" may be in this together, but we are not all human and we are not one and the same', Ecocene: Cappadocia Journal of
Environmental Humanities, 1(1): 26-31, doi: $<10.46863$ /ecocene.2020.3>.

Braidotti, Rosi, and Maria Hlavajova (eds.). 2018. Posthuman Glossary (London, Bloomsbury).

Campagna, Frederico. 2018. Technic and Magic: The Reconstruction of Reality (London: Bloomsbury Academic).

Damasio, Antonio, R. 1994. Descartes Error: Emotion, Reason and the Human Brain (New York: Avon Books).

- -2000. The Feeling of What Happens: Body and Emotion in the Making of Consciousness (London: Vintage).

Deleuze, Gilles. 1988. Spinoza: Practical Philosophy, trans. Robert Hurley (San Francisco: City Lights Books).

- 2006. Nietzsche and Philosophy, trans. Hugh Tomlinson (New York: Columbia University Press).

Deleuze, Gilles, and Felix Guattari. 1987. A Thousand Plateaus: Capitalism and Schizophrenia, trans. Brian Massumi (Minneapolis: Minnesota University Press).

- - 1994. What is Philosophy? trans. Hugh Tomlinson and Graham Burchell III (New York: Columbia University Press).

- 200o. Anti-Oedipus: Capitalism and Schizophrenia, trans. Robert Hurley et al. (Minneapolis, MN: University of Minnesota Press).

Dunn, Rob. 2019. The Wild Life of Our Bodies: Predators, Parasites and Partners that Shape Who We are Today (New York: HarperCollins Publishers Inc.).

Dupré, John. 2012. Processes of Life, Essays in the Philosophy of Biology (Oxford University Press).

Dupré, John, and Daniel J. Nicholson (eds.). 2018. Everything Flows: Towards a Processual Philosophy of Biology (New York: Oxford University Press), doi: <https://doi. org/10.1093/ oso/9780198779636.001.0001>.

Foucault, Michel. 1977. 'Nietzsche, genealogy, history', in Language, Counter-Memory, Practice: Selected Essays and Interviews, ed. Donald F. Bouchard (Ithaca, NY: Cornell University Press), 139-64.

- - 1978. History of Sexuality, vol. 1: An Introduction, trans. Robert Hurley (New York: Pantheon).

Fromm, Erich. 1976. To Have or to Be? (New York: Harper and Row). 
- - 1992. The Art of Being (New York: The Continuum Publishing Company).

--1994. On Being Human (New York: The Continuum Publishing Company).

Fuchs, Thomas. 2013. 'Zwischen Leib und Körper', in Leib und Leben. Perspektiven für eine neue Kultur der Körperlichkeit, eds. Marcus Knaup and Martin Hänhel (Darmstad: WBG), 82-93.

Grosz, Elisabeth. 1994. Volatile Bodies: Toward a Corporeal Feminism (Bloomington: Indiana University Press).

Haraway, Donna J. 2016. Staying with the Trouble: Making Kin in the Chthulucene (Durham, NC: Duke University Press).

- -2007. When Species Meet (Minneapolis: University of Minnesota Press).

Kant, Immanuel. 1998. Critique of Pure Reason, trans. P. Guyer and A. W. Wood (Cambridge University Press).

Keller, Catherine, and Mary-Jane Rubenstein. 2017. 'Introduction: tangled matters', Entangled Worlds: Religion, Science and New Materialisms, eds. Catherine Keller and Mary-Jane Rubenstein (New York: Fordham University Press), 1-18.

Kristeva, Julia. 1984. Revolution in Poetic Language, trans. Leon S. Roudiez (New York: Columbia University Press).

Lacan, Jacques. 2006. 'Kant with Sade', in Écrits, trans by B. Fink (New York: W.W. Norton \& Company), 645-68.

Laqueur, Thomas Walter. 1987. 'Orgasm, generation and politics of reproductive biology', in The Making of the Modern Body: Sexuality and Society in the Nineteenth Century, eds. Thomas Walter Laqueur and Catherine Gallagher (Berkeley: University of California Press), 1-41.

--1992. Making Sex: Body and Gender from the Greeks to Freud (Cambridge, MA: Harvard University Press).

McAfee, Noëlle. 2004. Julia Kristeva (New York: Routledge).

Margulis, Lynn. 2001. The Symbiotic Planet: A New Look at Evolution (London: Phoenix).

Mayer, Emeran. 2015. Mind-Gut Connection: How the Astonishing Dialogue Taking Place in Our Bodies Impacts Health, Weight, and Mood (New York: HarperCollins Publishers).

Moi, Toril. 1999. 'What is a woman?' in What is a Woman (New York: Oxford University Press), 3-120.

Neimanis, Astrida. 2013. 'Feminist subjectivity, watered', Feminist Review, 103: 23-41.

- - 2014. 'Alongside the right to water, a posthumanist feminist imaginary', Journal of Human Rights and the Environment, 5(1): 5-24.

-—2017. Bodies of Water: Posthuman Feminist Phenomenology (London: Bloomsbury).

Nietzsche, Friedrich Wilhelm. 1999a. 'Fröhliche Wissenschaft', in Sämtliche Werke: Kritische Studienausgabe, vol. 3, eds. Giorgio Colli and Mazzino Montinari (München: Deutscher Taschenbuch Verlag de Gruyter), 369-651.

- -1999b. 'Also sprach Zarathustra', in Sämtliche Werke: Kritische Studienausgabe, vol. 4, eds. Giorgio Colli and Mazzino Montinari (München: Deutscher Taschenbuch Verlag de Gruyter).

- -1999c. 'Die Geburt der Tragödie aus dem Geiste der Musik', in Sämtliche Werke: Kritische Studienausgabe, vol. 1, eds. Giorgio Colli and Mazzino Montinari (München: Deutscher Taschenbuch Verlag de Gruyter), 9-156.

Oksala, Johanna. 2005. Foucault on Freedom (Cambridge University Press), doi: <https:// doi.org/10.1017/CBO9780511597923>.

- -2016. Feminist Experiences: Studies in Phenomenology and Existential Philosophy (Evanston: Northwestern University Press).

Rose, Nikolas. 2007. The Politics of Life Itself: Biomedicine, Power, and Subjectivity in the Twenty-First Century (Princeton University Press).

—-2019. Our Psychiatric Future (Cambridge: Polity Press).

Rose, Nikolas, and Joelle M. Abi-Rached. 2013. Neuro: The New Brain Sciences and the Management of the Mind (Princeton University Press).

Sarasin, Philipp, 1998. 'Der öffentlich sichtbare Körper. Vom Spektakel der Anatomie zu den "curiosités physiologiques"', in Physiologie und industrielle Gesellschaft. Studien zur Verwissenschaftlichung des Körpers im 19.und 20. Jahrhundert, eds. Philipp Sarasin and Jakob Tanner (Frankfurt am Main: Suhrkamp), 419-52.

--2000. Reizbare Maschinen: Eine Geschichte 
des Körpers 1765-1914 (Frankfurt am Main: Suhrkamp).

--2009. Darwin und Foucault. Genealogie und Geschichte im Zeitalter der Biologie (Frankfurt am Main: Suhrkamp).

Sauka, Anne. 2020. 'The nature of our becoming: genealogical perspectives', Le Foucaldien, 6(1): 4, doi: <http://doi.org/10.16995/ lefou.71>.

Sennett, Richard. 1994. Flesh and Stone (New York: W.W. Norton \& Company).

Sheldrake, Merilin. 2020. Entangled Life: How Fungi Make Our Worlds, Change Our Minds \& Shape Our Futures (New York: Random House).

Stiegler, Bernard. 2014. The Re-Enchantment of the World: The Value of Spirit Against Industrial Populism (London: Bloomsbury Academic).

Tsing, Anna Lowenhaupt. 2015. The Mushroom at the End of the World: On the Possibility of Life in Capitalist Ruins (Princeton University Press).

Waldenfels, Bernhard. 2000. Das leibliche Selbst: Vorlesungen zur Phänomenologie des Leibes, ed. Regula Giuliani (Frankfurt am Main: Suhrkamp).

Žižek, Slavoj. 2010. Living in the End Times (London: Verso Books). 